\title{
Digital Economy and Communication Technologies: Methods and Mechanisms of Promotion through E-Commerce and E-Marketing
}

\author{
Foued Sabbagh
}

\begin{abstract}
This paper focuses on the methods and the mechanisms of E-commerce and E-marketing, and the important role of international electronic companies in this vital and digital field. The spreaders of the digital economy and the techniques of information and communication technology are deployed with applications of E-commerce and E-marketing. Thus, the digital globalization opens the horizon of technological development and accelerates the growth of the use of modern techniques through the innovation of the digital economy in our daily lives. In addition, the modernization of companies in the field of E-marketing and E-commerce has a direct impact on the strategic relationship between internet users, information, technology and business. In this sense, my theoretical study determines methods and mechanisms of promotion through E-commerce and E-marketing during the revolution of the digital economy and the technologies of modern and social communication.

Keywords: The Digital Economy, the Communication Technologies, E-marketing, E-commerce, Methods and Mechanisms.
\end{abstract}

\section{INTRODUCTION}

The term of digital economy or also internet economy refers to all economic and social activities that are enabled by the internet and the other information and communication technologies (Georgiadis C.K, Stiakakis E and Ravindron A.R (2013) [4]. Later on the issue of modern communication techniques is deployed with e-commerce applications and precisely in the early nineties of the past century. The spread and growth of this trade among one thousand thousands of human beings using these modern means have been positively contributing to the raising of profits and the rapid enrichment of electronic merchants.

\footnotetext{
Manuscript received on 11 May 2021 | Revised Manuscript received on 29 May 2021 | Manuscript Accepted on 15 June 2021 | Manuscript published on 30 June 2021.

* Correspondence Author

Foued Sabbagh*, Finance and Development, Faculty of Law and Economics and Politics Sciences/University of Sousse, Erriadh City, Tunisia. Email: fouedsabbagh_2010@yahoo.fr

(C) The Authors. Published by Lattice Science Publication (LSP). This is an open access article under the CC-BY-NC-ND license (http://creativecommons.org/licenses/by-nc-nd/4.0/)
}

What undeniable have strengthened the importance of business deal through online selling because of the increasing habit of this network it is puts the investment of these menus in the application of market principles through supply products and services and their distribution and upgrade.

Therefore launched the revolution of modern craft, which can be facilitating the process of selling and buying for millions of people with diligence and the effectiveness of quality and the promotion of diligently all the wares of the same process of marketing along the web. The study of Brynjolfsson E and Hitt L.M (2000) [2]. explain when the companies using information technology to change the way they conduct business often say that their investment in information technology complements changes in other aspects of the organization. Also the technological innovations related to the commercialization of the internet have dramatically decreased the cost of building electronic supply chain links. The evolution of modern techniques of communication on the net has helped electronic marketing of the business relationship between consumers and global electronics companies in a highly organized and courtly style. Selling is a profitable way companies profits you the most dividends and benefits a better spirit. The internet has become today on the important commercial space where the merchandise proposed for sale and are witnessing an increasing need for the purchase of these products by countless and not be brought into thoughtfulness. Fellowships to promote their products electronically have increased the sites for sale and purchase and increases with number of customer's promoters with commission the goods of these societies. Many people believe that e-commerce was one of the unsuccessful sites no approval, and no one buys or trusts and views them as fraud and elaborate, but lots more than that. Ba S, Whinston A.B and Zhong H (2002) [1]. says Millions of dollars change hands daily through online auction markets. However, fraud has been on the rise in these markets. Using a game theoretic approach, we propose a design of an economic incentive mechanism, the trusted third party (TTP), to serve the online auction communities. E-commerce to many sections according to the competence of each electronic enterprise, including commercial marketing by the company to the consumer (C2B), companies to companies (B2B), consumers to consumers (C2C), consumers to companies (B2C), Non-profit e-commerce (NonbusinessEC),

Published By:

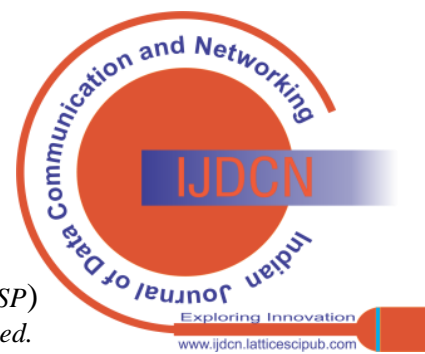


electronic business-to-business-to-consumer (C2B2B), in company (intra-business), business to its employees (E2B), cooperative trade (C-commerce) and government to its nationals or enterprises (E-Government).

I can give out the functions of electronic marketing via the marketing mix in force on the international markets of electronic commerce, for example search of the market of products and services, price, placement and distribution and also the announcement and promotion and publicizing. After demonstrating the e-commerce system via the marketing mix proceed to define the methods and mechanisms of electronic marketing of the products through the internet to turn it into a huge trading space containing all the wares of the countries of the whole universe. Beginning of all ways of furthering the division of the market, the positioning in the securities industry, the strategy of the market and types of marketing. Secondly, includes mechanisms for the packaging of products to many branches of trade companies of e-commerce and e-marketing and web marketing. Partial e-commerce, systems of information between the foundations and the electronic markets, systems of information between the institutions and theoretical accounts of shared income.

Some pass the e-marketing a radical transformation in the concept of trade close the internal market closed with a large external market open to the universe, including a great movement of supply and demand. The development of the e-marketing system to include modern changes in the world of digital engineering and e-commerce has become a major concern by officials declare as a plus element in limiting unemployment and offering chances to occupy many executives and graduates of universities, especially in the area of international trade, as well as provided a statement of substantial foreign exchange profit. The essay of Zhou L, Zhang P and Zimmermann (2013) starts by providing a brief overview of social commerce research and practice in light of the wide attention it has drawn in the industry. Then, we propose a research framework with an integrated view of social commerce that consists of four key components such as business, technology, people and information. In this paper of e-commerce and e-marketing, I will concentrate on electronic marketing methods and mechanisms and bases and international electronic companies in this critical and digital economy, also the important rule of information communication technology. Well, What is the concept of e-commerce and e-marketing in global markets?. How determines the promotion of products of international companies in this field?. And what are the methods and mechanisms of electronic marketing?

\section{ELECTRONIC COMMERCE}

Electronic commerce is a new concept emerged with recent developments in the area of digital globalization and advanced communication techniques. The universe of communications through internet networks is defined e-commerce as a means paves the way for the sale and purchase or exchange of merchandise, services and data. In addition, e-commerce applications are split into three parts, as follows the purchase and sale of so-called e-grocery store wares and services, facilitating and directing the flow of information and communication, and cooperation between societies and between different sections of a single company and ultimately to offer client service. The application of internet technologies to interfirm transactions has led to the amazing growth of internet-based business-to-business (B2B) electronic markets and online B2B sales (Dai Q and Kauffman R.J (2002)) [3]. The research on information technology and its impacts provides a rich resource for studying the various business models of B2B electronic markets and the dynamics of organizational adoption of electronic markets. I can classify electronic commerce through the nature of business transactions of international electronic companies. Fig.1. This classification represents the immense arena of sales operations or the purchase or exchange of merchandise, services and information via the internet and customers, or internal or external intermediary agents. This relationship forms the link between the tasks and the consumer or the direct relationship between one of them and some other.

\section{- Commercial Marketing of company to consumer} (C2B):

This transaction represents the cognitive operation of selling products, services and business-to-consumer exchanges, such as Dell and Amazon. This treatment is classified in direct sales to the consumer by retail sales without the presence of a commercial intermediary.

\section{- Commercial Marketing of companies to companies} (B2B):

The business relationship is essentially selling and buying between companies and it is in the aggregate of information systems between organizations and transactions carried out in electronic markets between companies. Dai Q and Kauffman R.J (2002) [3], affirms that synthesizing prior research on electronic markets, interorganizational information systems, and adoption of network technologies, we reveal that B2B electronic markets offer basic market functions, as some researchers have indicated, and that the current functionality base for electronic markets is beginning to emphasize other capabilities that aim to satisfy management information and risk management needs and enable technological adaptation and system integration.

\section{- Commercial Marketing consumer to consumer (C2C):}

Marketing represents the commercial exchange of the consumer to the consumer directly. The study of $\mathrm{Ba} S$, Whinston A.B and Zhang H (2002) [1]. confirm the creating of the trusted third party (TTP) because could be a great business opportunity. Just like Truste (http://www.truste.com) and BizRate (http://www.bizrate.com) are currently playing an important role in building trust in electronic markets, the proposed TTP model sheds light on a new type of TTp, which may significantly promote trust in online consumer to consumer (C2C) auction markets. While observing the procedure of selling a product between consumer and other consumer directly. Hence, the consumer has put ads on the website for sale for personal intentions or experiences. On that point are also auctions on the net like the eBay site. 


\section{- Commercial Marketing of consumers to companies} (B2C):

The commercial operation of individual consumers to companies that sell products or services to companies, such as the sale of handicrafts or traditional products to the companies failing the protection of the inheritance. Fig.5.

illustrates four essential elements of social commerce, their alignment and integration relationships, and strategic fit between strategy and infrastructure levels in each element strategic fit is inherently (Zhou L, Zhang P and Zimmermann H.D (2013)) [9]. This is because the choices made by one business enterprise or firm will evoke imitative actions over time, and this will necessitate responses from other competitors (Henderson J.C and Venkatraman N (1993)) [5]. This argument explains the social commerce with the strategic alignment concerns business, technology, people and information.

\section{- Electronic commerce non-profit (NonbusinessEC):}

This procedure represents the role of dissimilar types of e-commerce to reduce costs and improve the performance of government and not for profit psychiatric hospitals. Here we recall the religious and societal establishments.

\section{- Electronic commerce between companies} (Interbusiness):

This transaction presents the commercial exchange on the internal network of the company, which includes the exchange of products, services or data. The aim of this procedure is to bring down the costs of managing the psychiatric hospital and training workers on the cyberspace web.

\section{- Commercial Marketing of company to company to} consumer (C2B2B):

This transaction presents a trade exchange from one society to another and then to individual consumers. Here the company purchases the merchandise and then trade it to the retailer, and then sell it immediately to consumers.

- Commerce Marketing in a section within company (intrabusiness):

The commercial transaction represents all activities and internal information of the company regarding the interchange of goods and services or information between the different parts and individuals within the company without commercial intermediary. This case depends on several different units; each unit is specialized in the manufacture of specific pieces and sold to another unit within the troupe.

\section{- Commercial Marketing of company to its employees} (E2B):

The commercial exchange represents goods or services or information about the company to its individual personnel. Here, the company offers employees with certain products at a price and preferential returns the company immediately.

\section{- Cooperation commerce (C-commerce):}

The role of this cooperative commercial operation is to cooperate in electronic from among persons or groups at a distance to bear away the electronic commercial operation, such as the purpose and production of a product.
- Electronic commerce of government to citizens to companies (E-Government):

The operation represents the process of government coordination of the execution and simplification of management procedures through the purchase or supply of products or information, or to its individual citizens or companies through the Ministry's electronic website. Electronic government or so-called electronic public administration takes three main forms are:

- Relationship between the Government with Citizens (C2G)

- Relationship between the Government with the Government (G2G)

- Relationship between Government with Business (B2G)

The work of e-government represents the official expression of the knowledge society and the digital economy in the context of international economic and trade globalization in order to simplify relations with administrative structures and citizens and all clientele from a space.

\section{ELECTRONIC MARKETING}

The idea of electronic marketing via marketing mix began in the year 1964; and that by the theory of professor Harvard University of business Neil Borden. Fig.2. This method includes a mix it called the marketing mix contains 12 elements of marketing. However, Jérôme McCarthy and Four Buze are what proceeded to lay the foundations of this combination consisting of four capital letters beginning with letter "P". There is also a continuing debate in American universities as to whether to modify the elements of the marketing mix to manage the business of electronic marketing. Hence, all business parties are working to gain a larger share of the target market to strive to control and influence consumer buying behavior through the marketing strategies adopted. The global electronic companies have adopted a set of external influences in order to influence consumers buying behavior in order to rush to their product and to control the market through intermediaries, promotion agents and direct sales. The commercial marketing by the marketing mix method is made up of sP4 as well as the main element is reliance on market research that gathers communications and company, as well as the electronic marketing process on the internet combines elements electronic marketing mix as follows:

\section{- Marketplace Research:}

The marketing of a particular product proceeds first by identifying the needs and desires and preferences, and the behavior and reactions of prospective consumers, and the best way to reach the consumer is direct surveys through contacts or by notice of the survey. Also gather information about the market and determine the growing demand for the quality of this product. In addition, focus research on the study of competitors and market variables and product quality.

\section{- Product:}

The modern technologies have contributed to the allocation of additional services for a given customer.

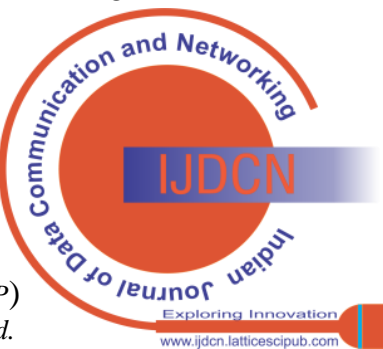


While the customer has become a consumer demand a given product online from some countries of the world and from any chosen retail store quickly and easily.

In addition, the consumer can access all types of products electronically within a few minutes. It could also for the consumer to request modifications specially adapted to his needs and desires.

Here the operation of the manufacture and production of the products required by the consumer takes home. Hence the operation of manufacturing products through the special website on sales as follows, the demand of consumers who wish by selection of design, painting, colors, size, measurement and other and then the customer make the purchase of products and the site make to manufacture required products and packing and shipping.

\section{- Pricing:}

The price is the main marketing substances to market any product through the internet, the consumer has become influenced to a large extent at the price of this product before buying it. The price of this product has made the calculation of rates of fees and taxes and insurance. These factors have a considerable influence on the consumer, where the latter by comparing the prices of a better and easier between a large number of competing electronic companies in the global market on the internet. The evolution of commercial marketing on the internet has opened up a wider field for the consumer to choose the right price for their needs and desires. Thus is done here the supplying operation wishing by the appropriate price and affordable on the other hand financial consumer of ability to pay the purchase of a paid product.

\section{- Promotion and Publicity:}

The use of modern technical means of the internet has allowed companies to adopt methods of promotion and propaganda and declaration of cost and high quality to attract consumers to buy a given product. This method facilitates the advertising work to inform the customers required for the quality and price of this product. It has also contributed to consumers' desires in modern high quality electronics. This promotional activity is known as a direct marketing communication activity with the customer required to tell him, or persuade him or remind him to accept or restitution purchase through a set of guidelines and advice. The marketing mix elements can be listed in the ad, promoting products according to the consumer's desires and market varieties.

\section{- Placement and Sell:}

The method of distribution followed by the company in accordance with the desires of consumers and through the carrier of the products of the factory and to the customer or consumer. The distribution includes the identification of targeted geographic areas and the place that wants the consumer as well as physical distribution, storage and direct transport. The evolution of modern electronic internet systems has become a global trading space, so that the consumer no longer needs to go to market, or the search for a product can not easily obtained, money. The distribution and sale on the internet with credit cards facilitates the operation of direct selling fast and high quality and high tech. In this raison, the information asymmetry may lead to market inefficiency, we can design and create trusted third parties to reduce asymmetric information, and thus to prevent potential market failure (Ba S, Whinston A.B and Zhang H (2002)) [1].

\section{THE METHODS AND MECHANISMS OF PROMOTION}

The operation to promote internet commerce based mainly on modern electronic promotion methods and mechanisms in world markets. The method of promotion includes market division, market targeting, positioning in the market, marketing strategy and approved marketing types. Electronic product promotion mechanisms can be categorized as e-business, e-market and network marketing, partial electronic commerce, data systems between institutions and electronic marketplaces, data systems between institutions and theoretical accounts of shared revenue. The commercial marketing of products on the internet begins with the elaboration of a global concept obviously to the objective of the company and the object of its creation. This way of marketing aims to develop legal frameworks and working bases of companies and their relations with their customers and intermediaries promoters of the products. In every commercial promotional success story lies electronic marketing in one hand on it. Marketing knowledge has become today the way to get rich quick in a knowledge society and digital economy. The purpose of the trusted third party (TTP) is to facilitate trust building in the online environment, and to help reduce online fraud through the use of reputation (Ba S, Whinston A.B and Zhang $H$ (2002)) [1]. The mechanism combines the digital economy and information communication technology aspects of online transactions. Controlling sales by commission or direct selling represent for some electronic merchant a way to derive considerable profits legitimately and legally.

\section{A. The Methods of Electronic Promotion}

The marketing profession is the conduct of all forms of activity of an electronic company that brings together all parts of traders, promoters, intermediaries and customers until the end of the product sales process. In this sens the classification of electronic commerce research by common topic such as the applications, technological issues, support and implementation and others methods increasing the volume of electronic commerce research has been conducted for a diverse range of areas (Ngai E.W.T and Wat F.K.T (2001)) [6]. Marketing defines for the company the market for its intervention and any merchandise for sale and promotional planning through the development of electronic sales methods. Fig.3. The marketing genius Philip Kotler recalls by applying his marketing analysis that the company's sound business resides in a suitable place of a place in the market. This theory can be summed up in three words (STP); Segmentation, Targeting, Positioning. In addition, one can increase the two important elements of promotional methods are the marketing strategy by analyzing the situation of the promotion and then defining the different types of marketing.

\section{- The division of market (Segmentation):}

The objective of this process is the segmentation of the market into several sections and groups to find broad areas can bring substantial profits in favor of the company.

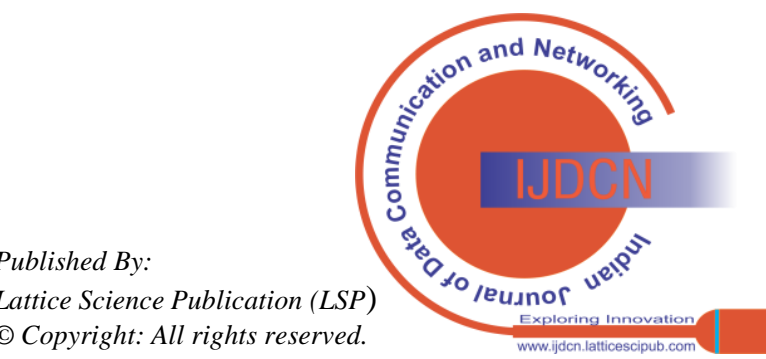


The very large market can be divided into three different ways:

$\checkmark$ The first method: it is essentially the demographic factor mention here the age, income, of education and employment.

An example of the company L'Oreal of cosmetics products eliminated the skin wrinkle said that it is destiny women by a factor of age between 35 to 50 years.

$\checkmark$ The second method: we can divide it markets here as needed because there are those who would like to make when out shopping with a request for a given product remotely. This slice of the population prefers purchases phone or internet connection and home or workplace. This method comprises essentially a category given individual in income is high or a level of Education is high, with experience of using applications of mobile phone or of the internet.

$\checkmark$ The third method: depends on the quality of the proportion of who preferred site promoter in the manner of behavior, and not by the intermediary their individual needs. Example a category of persons applying for food on site electronic particularly.

\section{Target market (Targeting):}

The advertisements have contributed decisively to the activity of the e-commerce market and thus to determine the characteristics of the activity of the company and their viability. The catch to target the market is to choose a fraction of their customers in relation to the products that incite the internet. Therefore, this targeting makes it possible to realize profits and lack of competition with other parts of the global electronic society that promote a particular product.

\section{- Positioning in the market (Positioning):}

This scientific term is marked in the marketing of electronic products with the authors of $\mathrm{Al}$ Ries and Jack Trout in 1982 in their book "The Conflict of Making the Mind". This is where the identification of the product to put it in front of customers elaboration within the minds of customers. The qualities of the products vary and take various forms, of which it is preferable and faster, and the safest and the cheapest and the most beautiful, but the marketing makes you in front of a single choice and that of identifying a single quality of one product want to buy. Marketing ensures you a given quality of a given company for a given tranche. The choice of a site within a market is identified product quality, is sold for a slice of customers have been convinced about the quality of this product.

\section{- Strategy of Marketing (Marketing Strategy):}

Each development of a marketing plan must contain essential elements and factors are identified before the start of trade promotion. The marketing strategy consists of setting goals that are timely and appropriate and studying all possibilities. Fig.3. The marketing strategy plan is articulated in five things that they call C Five's letters (5C's) and are customers (Customers), company (Company), competitors (Competitors), collaborators (Collaborators); content (Context). These factors are considered the most important part of marketing for you and for your business and your company and you have made considerable profits.

$\checkmark$ Customers Analysis: The promotion of a particular product requires an analysis of the characteristics of virtual customers through appropriate selection of the product to their desires. In this regard, researchers found in the marketing field of the existence of five roles played someone at the completion of a purchase transaction. Therefore, these distinct roles are distributed according to needs and desires as well as the sponsor's tracking and analysis.

- Initiator: Product internet search of desire

- Reporter: to take the decision that suits his needs and desires

- Affluent: affected by operations promotion and not to take the final decision of purchasing

- A consumer purchaser: the customer is put in out with success the process of purchasing a product

- User: the one who makes use of a product that has purchased

$\checkmark$ Company Analysis: The operation is done by analyzing the capabilities and points of weakness of the company and a product offers promotion. In addition to the analysis of the financial capabilities and productivity on the one hand, and their capacity of research and development on the other part. It is necessary to identify all the assets of the productive society of the product under consideration.

$\checkmark$ Competitor Analysis: In this area of analysis of competitors in the electronic market must first determine the current and potential competitors. In addition to understand the points of their strength and weakness so well. And therefore to put the methods and special means for the commercial marketeur of the different product and distinct from the others. In addition, the objectives of competitors and strategies must also be assessed in order to anticipate competitors' reactions in the electronic market.

$\checkmark$ Collaborator Analysis: Global electronic companies cannot do everything themselves for this, you need these companies to many promoters and intermediaries of the company and products for sale. There partners are considered the company of collaborators, such as distributors and suppliers. It is appropriate in this regard to analyze the quality of the promoters through understanding and a good appreciation potential of each partner of the company you can depend on the promoter in time and the right places to sell.

$\checkmark$ Context Analysis: The marketing policy electronic commercial products on the internet or marketing through the direct sale not fixed and its content always change. The events of the world have known in the field of digital technology in a direct relation to the culture of the customers and which can produce unexpected surprises for the marketer. The value of products and services determines the needs and desires of buyers and changes in the company culture, such as Pepsi, McDonalds and Adidas. These evolutions are called in the commercial marketing by the fashion, the chic and the last mark. While the value of the proposed products whose sale affected and changed the culture of buyers. These results must be identified and analyzed and taken into consideration.

treger a 14

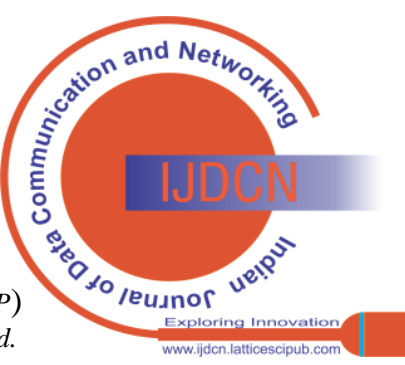


Thus, Jack Welch the most famous director of e-government over the past twenty years has shown that marketing is not the task of the workers, and the task of all employees of the company.

\section{- Types of electronic marketing (e-Marketing Types):}

The evolution hat has experienced the modern technological sciences and the digital space in the knowledge society and the digital economy make the internet network a considerable commercial space for all parties concerned by local or national authorities in electronic trader and distributors. Thus e-commerce has also become a scientific and professional culture and taught their programs in major business and commerce universities around the world. Electronic marketing has become the important necessitie of life institutions and factories and local and international trading companies. Some of the millions of people who log on to the internet every day into network all over the world, particularly by means of social communication and electronic mail. He also became a global internet marketing chain and a large-scale open market internationally to promote products and services and become as a business space for high financial returns of profits. Fig. 6. Zhong Y (2012) [8]. explores the concepts of social commerce, the behavior of consumers in social commerce, business models and revenues models of social commerce. In our world 350 million users are engaging with Facebook on mobile phones, also other use more social media platform or connect with e-mail. The information and communication technology (ICT) adopting one model maybe very useful tool for explore the motivation of consumers in social commerce. In addition, the internet has become the commercial area of the capital without entrepreneurs or a simple cost has made considerable profits. All the government studies the world has shown that e-commerce represents a new generation of modern commerce and traditional commerce has become the past. Also, all the reports confirm that the new rich in the world are those that can create commerce sites on the internet or to promote products through direct sales. What is beyond doubt that remote working on the internet has added means of promotion are the following types can be cited:

- Sites ads free online

- Public forums and indexes websites

- Directories and indexes websites

- Pages websites

- Sites of social media

- Sites of videos

- The announce with clics in research motors

- The announce with clics in social sites

- E-mail announce and campaigns of promotion

- Sites of paying ads

- Blogs of company to through direct communication with customers and explain products

- Magazines and electronic journals

- The announce by search engines

- Web design to make known to be the products and services

- The creation of commercial shops electronic

- Advertising sites of propaganda

- Marketing through recommendations

Among the most important points that are added by the website to understand the needs and desires and client actions on electronic and commercial websites and understand what they like and what they do not want. As a scientific evaluation and professional implementation and the effectiveness of advertising campaigns

e-marketing.

\section{B. The Mechanisms of Electronic Promotion}

The sale transaction or the purchase or exchange of goods and services and information on the Internet depends on many promotion mechanisms based on the competence of each electronic company in a given field of marketing and sales. The evidence on how investments in information technology are linked to higher productivity and organizational transformation, with emphasis on studies conducted at the firm level (Brynjolfsson E and Hitt L.M (2000)) [2]. Over the last decade of research of the new mechanisms of marketing by new strategies of promotion since then has substantially improved the understanding of the relationship between information technology, organizational transformation and business performance. Fig.4. The multiple expressions of e-commerce take many forms and different among them electronic commerce there is (e-business), electronic market (e-marketplace), web, network marketing (Network Marketing), partial electronic commerce (Click-and-mortar), information systems between institutions and electronic markets (Interorganization information systems), between institutions of information systems (Intraorganization information systems) and common revenue models (Marketing models).

\section{- E-business:}

We can define e-business as the concept of the use of modern technologies and electronic networks for the development and distribution of commercial business or the creation of new virtual business. This definition develops basic frameworks of e-commerce and the distribution of roles and identifying relationships between clients, brokers, developers and business partners. In addition to it to make the electronic business transactions and trade through the sale or the purchase of products and services and information.

\section{- E-marketplace:}

The revolution in digital communication technologies has developed a new concept of the economy is the digital economy, and also called the internet economy, the new economy, or the economy of the web. This definition is the expression of a commercial market represents the exchange of products electronically and a forum between the seller, the buyer and promoter of different products. In addition to the financial operations and the exchange of electronic information through the internet.

\section{- Network Marketing:}

It is the expression of commercial marketing of products through internet applications that will help to keep the business partners or friends or people who share specific concerns through research needs and desires of the individual products. Thus, through direct sales between individuals and by product definition and to promote a commission through a social network of all distributors and recipients.

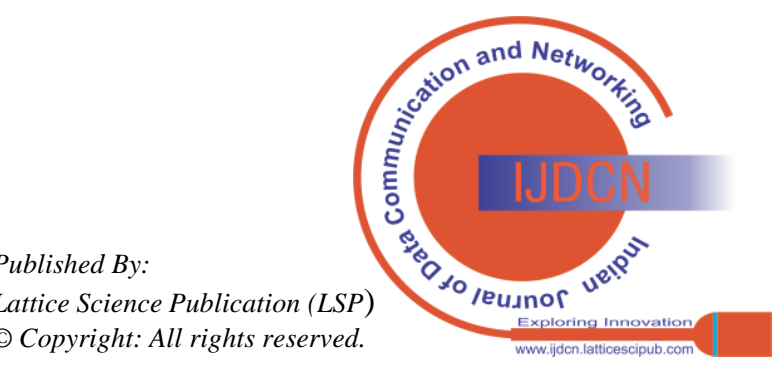


The web marketing network was named the company of people means that anyone can relay this business and become the director of an international company at a local or international distributor to provide a service to a network of abandonment of the parent producers of the products to bear the burden of administration and sales promoters in favor of their product in exchange for equipment to be determined according to the number of customers and the commission polarizer's obtained by the distributor.

\section{- Partial e-marketing (Click and mortar):}

Tables.1. The digital economy is a series of economic, social and cultural activities that are performed online and are related to the use of information and communication technology (ICT). Grace to these statistical tables, we observe an upward trend in the use of information and communication technology (ICT), as well as investments in this filed particularly in developed countries such as France and Japan. The Digital economy is convergence of economy, informatics, (tele) communications, computing and digitalisation. It is based on intangible resources such as information, innovation, creativity, etc (Zupan G (2016)) [10]. The main elements of digital economy are digitalisation and livel of ICT usage, conversion of information into market value and new ways of organising the economy, business processes, work and production. Growth of digital economy has an impact on the entire economy. More intensive ICT usage, and the changing of consumer habits demand that entreprises and organisations adjust to new conditions and exploit the advantages of the digital world. In this sens, The partial electronic marketing is the most common combination of traditional, digital economy, ICT and e-commerce trade, where the operation of electronic commerce is divided into two parts the first electronic part and the second concrete. While the product that the promoter combines two types of trade.

\section{Interorganization information systems}

These systems represent the exchange of information and control by the electronic link between companies or organizations. The fundamental purpose of this remote electronic transaction is to perform effective way of operations such as sending financial orders, payments of invoices and bills of exchange and bank checks through external networks. Relations between the parties involved in the internet for a key aim of simplifying financial transactions on the local or international level. Electronic marketing, bringing together sellers and buyers to tender and climb in prices and operationalize the system of remote electronic payment. The difference between the systems between institutions and electronic markets is that the first applications using corporate companies and the second users corporate applications to companies and consumers corporate applications.

\section{- Intraorganization information systems:}

We can see from the statistical tables 2. Access to broadband and broadband subscriptions in the wireless or fixed telecommunications system, as well as the use of these means for business and commerce, as well as the increasing number of households that have extensive communication customers and commissions. Network marketing is the

especially in France, Japan and Germany. New communication technologies have provided the electronic marketplace and remote payment system between several commercial entities and often include a particular company and their supplier and consumer. These systems of information between the institutions through special and commercial communications networks can sellers and buyers organize daily business relationships. We can divide the types of information systems between institutions:

- Electronic Data Interchange EDI

- Extranet

- Electronic Funds Transfer

- E-Application

- Telecopy and Email

- Basic Information Decomposed

- Supply Chain Management

These electronic systems that provide the latest services through digital communication technologies are considered to simplify transactions for companies to companies or organizations to companies or companies to organizations or companies to consumers. In addition to trade through the reception and the storage and transmission of common data between companies and their customers and suppliers through the promotion and the applications of e-commerce.

\section{- Marketing Models:}

The working models of application e-commerce of electronic commerce is centered on support services to electronic market and organize trade and relations between sellers, buyers, the administrative relations public, the announcement and the promotion. The infrastructure of telecommunications and information technology companies comprise a common working model. Therefore we can determine the structure and characteristics of a model of this work, and this model by common recipes. These models are divided into:

- Transaction fees model

- Subscription model

- Advertisement model

- Affiliate model

- Sales model

These models represent a marketing strategy by modern techniques of commercial communications governing remote financial transactions, subscriptions and paid advertisements, promotion and sale of products and services. The common revenue models represent the model of global electronics companies and to make profits and revenues for the survival of the electronic market.

\section{CONCLUSION}

The digital economy is not a totally new economy, but rather the whole of new ways to accomplish the usual economic and social activities through the use of information and communication technology (Georgiadis C.K, Stiakakis E and Ravindron A.R (2013)) [4]. Historically, the commercial Marketing or, rather, it called the electronic marketing is considered such as the commerce of XXI eme.
Published By:

Lattice Science Publication (LSP) (C) Copyright: All rights reserved.

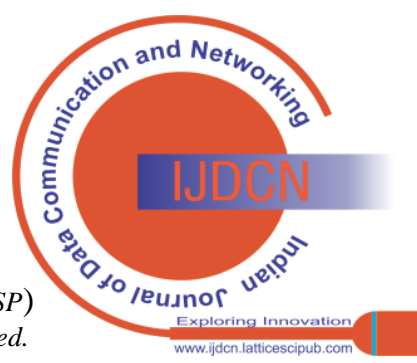


As it is explained the genius of electronic marketing Kotler in his book the importance of marketing to acquire customers and intermediaries or promoter by commission responsible to the operation of the sales and marketing. The internet usage is not limited to only home, workplace, school, etc, or the access via fixed internet connections.

Persons access the internet with mobile devices (laptop or tablet computers, mobile or smart phones, e-readers, smart watches) via mobile internet connections anytime and anywhere (Zupan G (2016)) [10]. Mobile internet connections enable connectivity anywhere and thus access to information anytime and anywhere. Ever faster mobile internet connections enable the development of new services and change the every day life and operation of enterprises. The marketing has helped by the network of the internet companies global electronic targeting a broader market and more large and access to its products and its services to the largest database of customers directly or through the intermediary of the proponents by the commission and do so in a more simple and less expensive. The new technologies of communication among the millions of daily lives on the internet have contributed to the development of the system the commercial marketing of the products of companies global electronic. Electronic commerce has become the culture of the digital society which has become buys and sells through the largest global sites, as well this trade has developed through the relationships between companies, consumers and the government. The electronic commerce depends essentially of commercial transactions by the sale and purchase direct or through an intermediary, as well as to the growing demand of modern products to meet the needs and desires of consumers. If you wanted to make a project without capital or for a modest cost, then you must learn to create sites and electronic shops and be qualified to an experience of the trade of the XXI century. If your sites and your attractive shops and organized and clean and therefore you received to the financial benefits of considerable legitimate way and legal. In addition to concentrate on the marketing campaigns that are important factors to attract the customers and the direct sales or electronic. The evolution of electronic marketing via the marketing mix to give real opportunities to electronic traders and global corporations to diversify the products and services, price fixing and localization and facilitated the distribution, of the announcement and the promotion and advertising and to develop the research on the market. This area helped to reach the largest possible number of customers at a lower cost and to communicate directly with them. The commercial marketing thanks to the methods and mechanisms for the promotion and to define a global concept obviously to the objective of the company and its relations with all the parties in the electronic market. These objectives include a division of the market, target markets, positioning in the market and of the analysis of the marketing strategies and to control the types of marketing. These methods and mechanisms represent the fundamental objective thanks those can companies global electronic to respond to the needs and desires of clients so as to bring considerable profits. In addition, mechanisms for promoting represent the source of development the system of electronic business, the electronic market open and marketing in the web network, the trade in detail, information systems and models of common revenue. If it has won the bet of the market, you will earn profits through an increase in customers and to obtain a commission in exchange. All world reports show that electronic commerce has become in exchange by the billions, in addition to the major electronic financial transactions between traders and buyers. The exchange electronic trade opens the way to the electronic globalization and the development of the new communication technologies and the digital economy to all countries of the world. Therefore to be in success in this area, you will not be alone or isolated the source of wealth is your customers and your language and your relationship with buyers and persuade them by your product promotion, and intended for the sale. It must be friction should the holders of expertise and professional experience in this field and to learn about them and to benefit from their experience. The rich of the new word are the electronic traders because they have all the companies and all the products which innumerable and without capital so they can the sale of thousands of products per day. The traditional trade has need of capital in the transaction for the purchase of products, a local commercial, customers and an administration, distribution and accounting and therefore this trade is considered limited and costly and non cost effective in relation to global electronic commerce.

\section{REFERENCES}

1. S. Ba, A.B. Whinston, and H. Zhang, (2002), « Building trust in online auction markets through an economic incentive mechanism », Decision Support Systems 970 (2002), xxx-xxx.

2. E. Brynjolfsson, and L.M. Hitt, (2000), « Beyond Computation Information Technology, Organizational transformation and Business Performance ", Journal of Economic Perspectives, Vol.14, $\mathrm{N}^{\circ} 4$, pp.23-48. [CrossRef]

3. Q. Dai, and R.J. Kauffman, (2002), «Business Models for Internet-Based B2B Electronic Markets ", International Journal of Electronic Commerce, Vol.6, Nº4, pp.41-72. [CrossRef]

4. C.K. Georgiadis, E. Stiakakis, and A.R. Ravindran, (2013), « Editorial for the special issue: Digital Economy and E-Commerce Technology », Springer-Verlag, Oper Res Int J. (2013), Vol.13, pp.1-4. [CrossRef]

5. J.C. Henderson, and N. Venkatraman, (1993), « Strategic alignment: leveraging information technology for transforming organizations », IBM Systems Journal, Vol.32, N¹, pp.472-484. [CrossRef]

6. E.W.T. Ngai, and F.K.T. Wat, (2002), « A literature review and classification of electronic commerce research ", Information \& Management, Vol.39, pp.415-429. [CrossRef]

7. F. Sabbagh, (2017), « Electronic commerce and electronic marketing: Methods and Mechanisms of promotion ", Édition Knoowy, Study Documents.

8. Y. Zhong, (2012), " Social Commerce: A New Electronic commerce », Eleventh whan international conference on e-Business, Vol.49, pp.164-169.

9. L. Zhou, P. Zhong, and H.D. Zimmermann, (2013), « Social commerce research: An integrated view », Electronic commerce research and applications, Vol.12, pp.61-68. [CrossRef]

10. G. Zupan, (2016), « E-Skills and Digital economy », Statistical Office of the Republic of Slovenia.

\section{AUTHORS PROFILE}

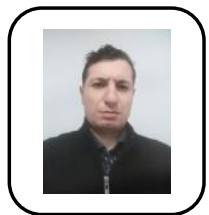

Foued Sabbagh, Masters Degree in economics sciences specialty Finance and Development in 2010 from the Faculty of Law and Economics and Political Sciences of Sousse - University of Sousse Tunisia and International Economic Researcher, fouedsabbagh_2010@yahoo.fr -

https://www.academia.edu/FouedSabbagh

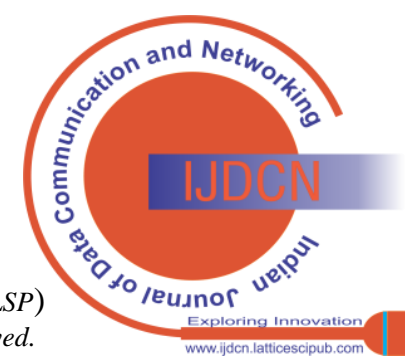




\section{ANNEXES}

Fig.1. Electronic commerce

\begin{tabular}{|l|}
\hline Marketing (Commerce) Company to Consumer (B2C) \\
\hline Marketing (Commerce) Companies to Companies (B2B) \\
\hline Marketing (Commerce) Consumer to Consumer (C2C) \\
\hline Marketing (Commerce) Consumer to Company (C2B) \\
\hline E-Commerce No-profit (NonbusinessEC) \\
\hline Electronic commerce between institutions (Interbusiness) \\
\hline Marketing (Commerce) of the Company to Company to Consumer (B2B2C) \\
\hline In a section within the Company (Intrabusiness) \\
\hline Of the Company to its employees(B2E) \\
\hline Cooperative Commerce (C-commerce) \\
\hline Government to its nationals or to Companies (E-Government) \\
Source : Foued Sabbagh (2017)
\end{tabular}

Fig.2. Electronic Marketing (Marketing Mix)

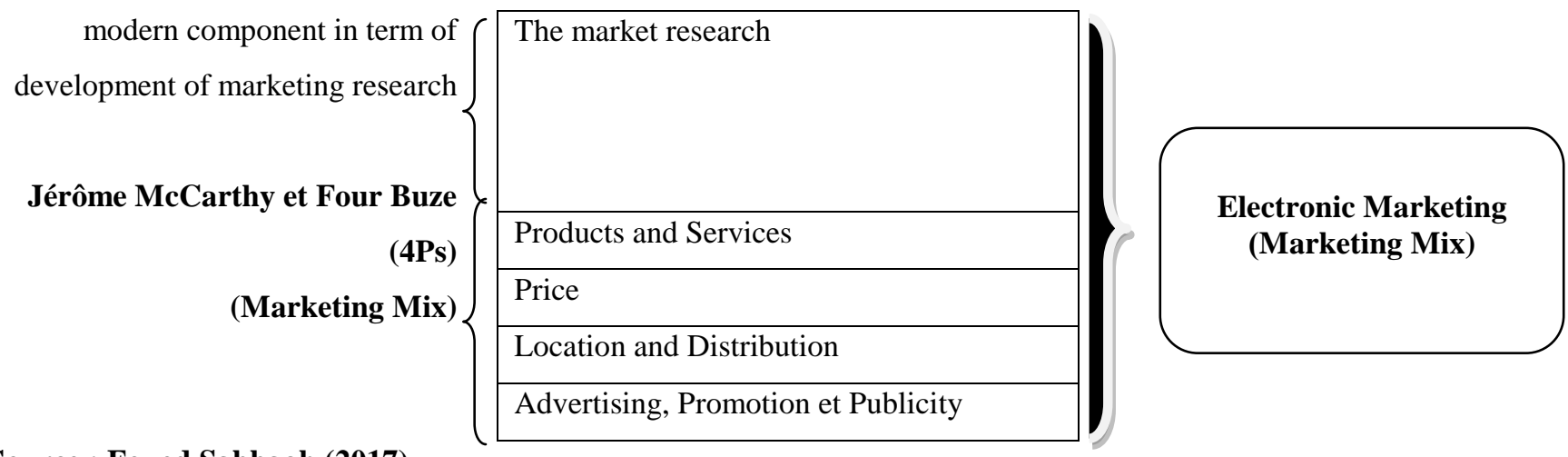

Source : Foued Sabbagh (2017)

Fig.3. Methods of Promotion

\begin{tabular}{|c|c|c|}
\hline \multirow{3}{*}{$\begin{array}{c}\text { Philip Kotler } \\
\text { (STP) }\end{array}$} & Segmentation of the market & \multirow[b]{5}{*}{ Methods of promotion } \\
\hline & Target of markets & \\
\hline & Positionnement in market & \\
\hline \multirow{5}{*}{$\begin{array}{l}\text { Strategies of Marketing } \\
\qquad\left(5 C^{\prime} \text { 's) }\right.\end{array}$} & Analysis of Clients & \\
\hline & Analysis of Company & \\
\hline & Analysis of competitors & \\
\hline & Analysis of collaborators & \\
\hline & Analysis of content & \\
\hline \multicolumn{2}{|r|}{ Types of Marketing } & \\
\hline
\end{tabular}

Source : Foued Sabbagh (2017) [7]

Fig.4. Mechanisms of promotion

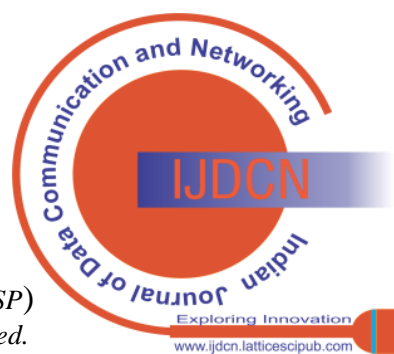


Digital Economy and Communication Technologies: Methods and Mechanisms of Promotion through E-Commerce and E-Marketing

\begin{tabular}{|l|}
\hline Electronic business (E-business) \\
\hline Electronic marketplace (E-Marketplace) \\
\hline Network Marketing (Network Marketing) \\
\hline Partial electronic commerce (Click-and-mortar) \\
\hline Information systems between institutions and electronic markets \\
(Interorganization Information Systems) \\
\hline Information systems between institutions (Intraorganization Information Systems) \\
Source: Foued Sabbagh (2017)
\end{tabular}

Fig.5. An integrated view of social commerce research

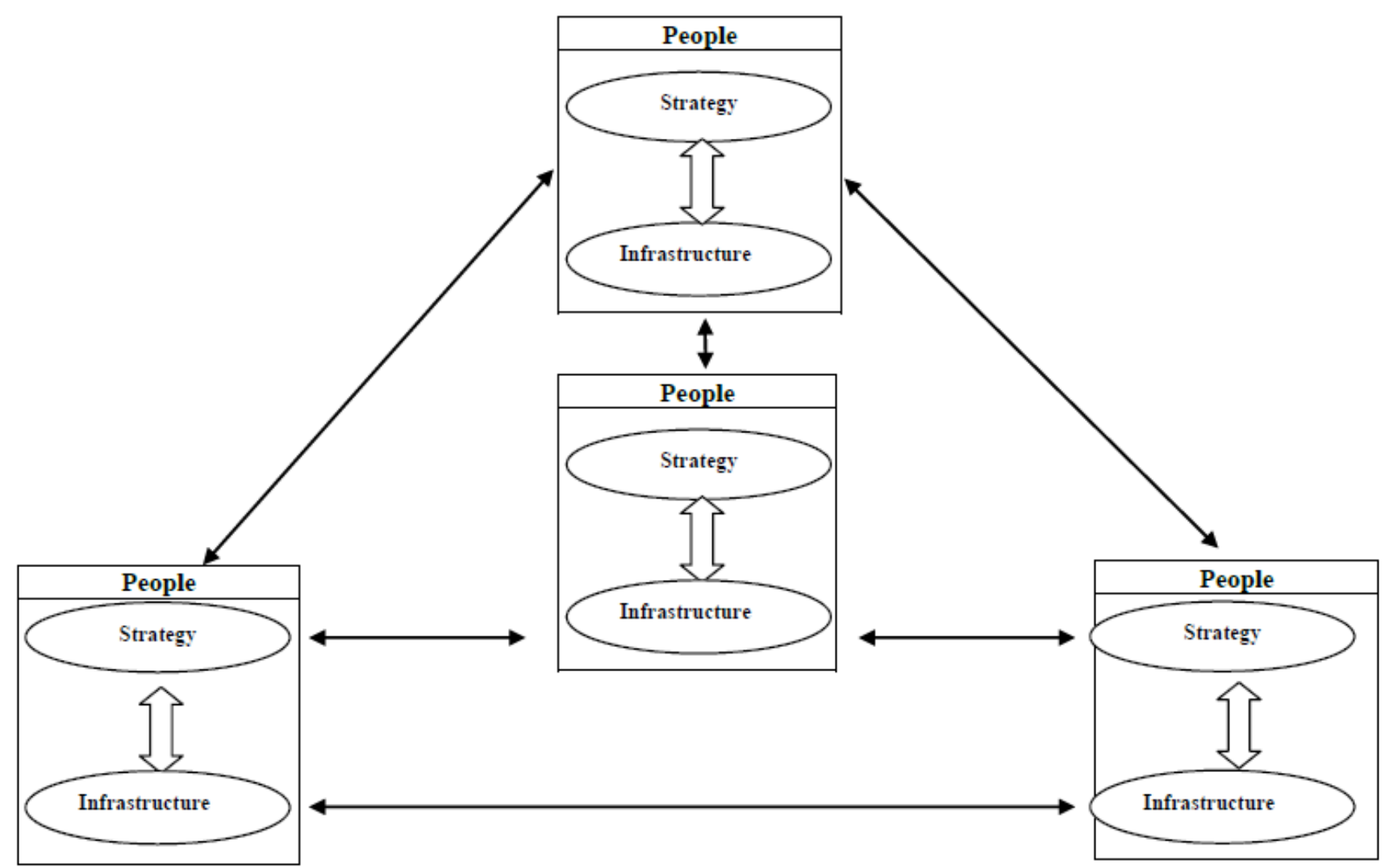

Source: Lina Zhon, Ping Zhang and Hans-Dieter Zimmermann (2013)

Fig.6. A concept Model of Social Commerce

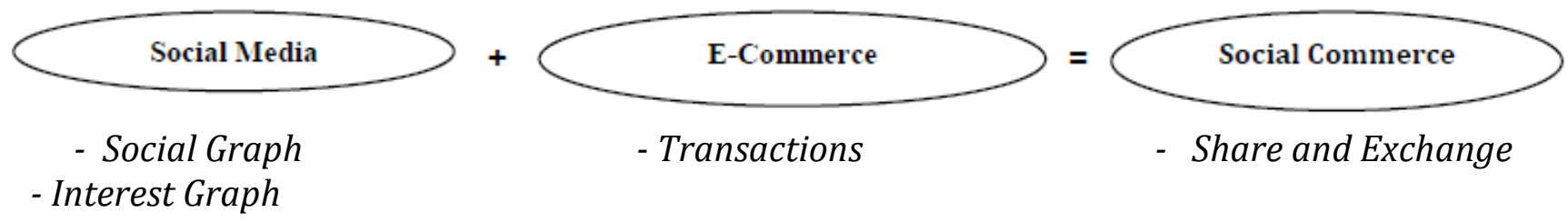

Source: Yao Zhong (2012)

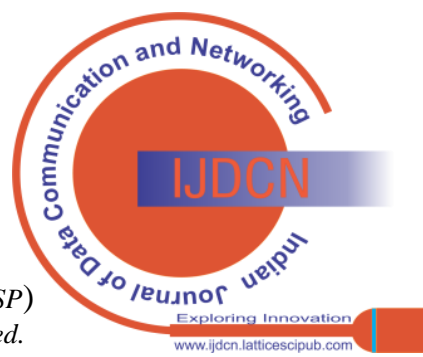


Tables.1. Information and communication technology (ICT)

\section{1 . ICT Value added}

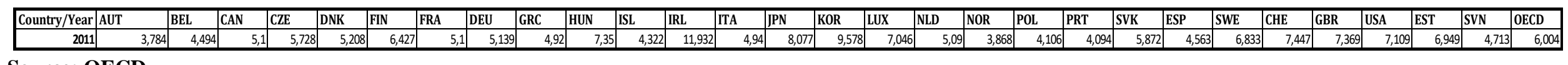

\section{Source: OECD}

1.2 . ICT employment

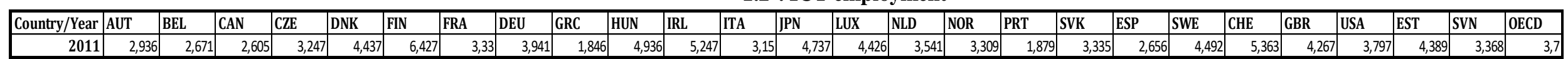

Source: OECD

\section{3 .ICT investment}

\begin{tabular}{|c|c|c|c|c|c|c|c|c|c|c|c|c|c|c|c|c|c|c|}
\hline Country/Years & AUS & AUT & CAN & DNK & FIN & FRA & DEU & IRL & ITA & JPN & KOR & NLD & NZL & ESP & SWE & CHE & GBR & USA \\
\hline 1985 & 12,46545 & 9,169517 & 11,06016 & 20,79865 & 2,798417 & 12,22104 & 13,25454 & 6,625801 & 10,71491 & 7,367463 & 9,413975 & 12,05999 & 13,2586 & 13,98335 & 15,04196 & \begin{tabular}{|l|}
13,47824 \\
\end{tabular} & 13,9476 & 21,45438 \\
\hline 1986 & 13,93953 & 371909 & 11,53996 & 19,93597 & 3,444224 & 12,39109 & 13,09243 & 5,789756 & 11,60053 & 7,922849 & 9,202438 & 12,27686 & 15,57856 & 14,57282 & 15,43408 & 13,70828 & 15,59967 & 22,6436 \\
\hline 1987 & 14,14243 & 631163 & 12,52035 & 20,83263 & 3,598105 & 12,65487 & 13,3633 & 6,103586 & 12,232 & \begin{tabular}{|l|l|}
2,356115 \\
\end{tabular} & 10,04053 & 12,8523 & 14,91048 & 15,16134 & 15,80401 & 13,63599 & 15,80262 & 22,92677 \\
\hline 1988 & 14,28999 & 9,772236 & 40965 & 95658 & 3,79193 & 62666 & 13,65549 & 35976 & 12,58228 & 8,960974 & 9,440109 & 13,47698 & 16,33011 & 15,11891 & 16,47545 & 13,66174 & 15,9304 & \\
\hline 1989 & 15,34871 & 9,748974 & 12,56532 & 17,22341 & 3,893099 & 12,63232 & 13,79488 & 7,443723 & 12,31637 & 9,411935 & 8,931326 & 14,5972 & 18,52424 & 14,55102 & 15,48188 & 13,48609 & 16,18097 & 24,09065 \\
\hline 1990 & 22827 & 9,804382 & 22704 & 17,75518 & 4,865744 & 11,9079 & 97038 & 6,085564 & 12,15081 & 9,089892 & 8,403208 & 14,70597 & 20,47944 & 13,69028 & 15,2119 & 13,48156 & 3475 & \\
\hline 1991 & 06236 & 10,17385 & 4,2392 & 18,33673 & 6,489717 & 0943 & 55591 & 6,645843 & 12,17319 & 9,326125 & 7,526111 & 15,30192 & 22,48203 & 12,46535 & 16,80417 & 13,26068 & 18,20753 & 25,41451 \\
\hline 1992 & & & 444 & & & & & 5519 & & & 7,27434 & 15,0519 & 22,14974 & 2012 & & 33947 & 18,5102 & \\
\hline 1993 & 18,94611 & 10,15263 & 16,93998 & 21,2854 & 12,25767 & 12,48247 & 13,20642 & 6,910261 & 12,91146 & 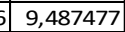 & 7,181278 & 15,69932 & 19,67615 & 12,5653 & 26,44925 & 14,67357 & 19,06223 & 26,75113 \\
\hline 1994 & & 10,81663 & & 21,26985 & 14,81294 & 13,05556 & 33926 & 7,648467 & & 9,487759 & 7,749645 & 37263 & 19,87493 & 12,86528 & 46372 & 27669 & 82338 & 26,60711 \\
\hline 1995 & 8,47078 & 11,25791 & 16,77352 & 19,72702 & 17,29159 & 13,887 & 13,29467 & 11,11246 & 12,96403 & \begin{tabular}{|l|l|}
3 & 10,61348 \\
\end{tabular} & 9,296171 & 15,69783 & 18,94381 & 12,5073 & 24,84148 & 14,03459 & 2,98488 & 27,17379 \\
\hline 1996 & 19,23341 & 10,7935 & 03033 & 18,52495 & 12,8957 & 15,46667 & 14,1195 & 12,0671 & 13,66055 & 12,6221 & 9,993333 & 16,40936 & 18,87522 & 14,56187 & 24,08433 & 4,59526 & 5,11871 & 27,78731 \\
\hline 1997 & 20,44956 & 11,21908 & 17,51579 & 19,77524 & 12,3367 & 17,53333 & 14,44019 & 10,27669 & 14,80362 & 12,15022 & 10,91463 & 17,94364 & 20,61516 & 14,4778 & 25,58622 & 16,29766 & 3,84561 & 28,93265 \\
\hline 1998 & & & 7651 & & 13,80964 & & 2412 & 54346 & & $11,99 \angle 31$ & 12,79183 & 36765 & 24,36388 & 2177 & & 53643 & 58335 & \\
\hline 1999 & 21,51975 & 13,54934 & 19,90437 & 21,62197 & 14,59312 & 19,86494 & 6,46835 & 11,00513 & 13,86458 & \begin{tabular}{|l|l|}
3 & 13,03914 \\
\end{tabular} & 15,7968 & 19,11492 & 23,28518 & 14,91094 & 28,79766 & 7,51743 & 7,18326 & 30,97586 \\
\hline 2000 & & & & & & & & 4115 & & & 18,02916 & 19,85098 & 26,13139 & 66577 & & & 2729 & \\
\hline 2001 & 22,54178 & 3,99849 & 0,19332 & 19,20074 & 1,74204 & 20,51282 & 17,51308 & 11,17843 & 13,63651 & \begin{tabular}{|l|l|}
1 & 15,08194 \\
\end{tabular} & 16,99673 & 19,9392 & 22,31824 & 14,27924 & 27,90616 & 7,76348 & 8,03881 & 31,15105 \\
\hline 2002 & 19,88743 & 14,52103 & 2329 & 22,01632 & 0097 & 1937 & 16,64899 & 9,275265 & 12,33842 & 14,8342 & 15,70482 & 19,12895 & 21,09387 & 13,8038 & 26,1875 & 18,88256 & 26,46331 & 30,33779 \\
\hline 2003 & 19,65725 & 13,13209 & 18,75371 & 22,05129 & 14,45046 & 422 & 15,06852 & 9,103434 & 11,60413 & 14,84725 & 13,23979 & 20,01081 & 21,82578 & 13,60955 & 24,94157 & 18,2971 & 50124 & 30,53394 \\
\hline 2004 & 095 & \begin{tabular}{|l|l|}
12,38379 \\
\end{tabular} & 3839 & 7141 & 14,44915 & 17,63902 & 14,52497 & 8,994478 & 601 & 3961 & & 88448 & 21,65919 & 1799 & 5572 & 0146 & 276 & 203 \\
\hline 2005 & 15,33718 & 11,88726 & 17,59781 & 24,80212 & 14,98808 & 17,45081 & 14,98392 & 7,527052 & 11,66963 & 14,30709 & 3533 & 99082 & 21,6027 & 12,7137 & 7846 & 8,35375 & 50004 & 27,779 \\
\hline 006 & \begin{tabular}{|l|}
14,63537 \\
\end{tabular} & 12,10717 & 1314 & & 3311 & 2811 & 9355 & 8,984832 & 10,90942 & 5308 & 7351 & 22,27951 & 22,31121 & 12,72055 & 24,36486 & 0816 & 24,74603 & 26,71907 \\
\hline 2007 & 14,21203 & 12,28721 & 16,65547 & 24,57366 & 14,27948 & 16,23711 & 13,96518 & 8,871742 & 10,74138 & \begin{tabular}{l|l}
3,39941 \\
\end{tabular} & 12,14019 & \begin{tabular}{|l|}
19,54825 \\
\end{tabular} & 22,41765 & 13,13256 & 23,03741 & 17,73105 & 23,7657 & 26,31124 \\
\hline 2008 & \begin{tabular}{|l|}
13,78564 \\
\end{tabular} & & 15,86403 & & 12,82297 & & 13,04645 & 7,546465 & 10,4188 & 13,5321 & 11,71829 & & 22,86724 & 13,63852 & 21,93484 & \begin{tabular}{|l|l|}
4 & 17,92638
\end{tabular} & & \\
\hline 2009 & & & 17,47223 & & 14,42818 & 16,33962 & 13,23498 & 11,2979 & 10,9079 & & \begin{tabular}{|l|}
11,35816 \\
\end{tabular} & & 21,61938 & 13,70693 & 24,74626 & 18,78993 & & 30,61006 \\
\hline 2010 & & & 17,01837 & & 15,51983 & & 12,69039 & 12,41281 & 11,02606 & & \begin{tabular}{|l|l|}
10,71603 \\
\end{tabular} & & 21,23818 & 13,76342 & & 18,50669 & & 32,137 \\
\hline
\end{tabular}

Source: OECD

Retrieval Number:100.1/ijdcn.B5003021221 DOI:10.54105/ijdcn.B5003.061321

Journal Website: www.ijdcn.latticescipub.com
Published By:

Lattice Science Publication (LSP)

(c) Copyright: All rights reserved.

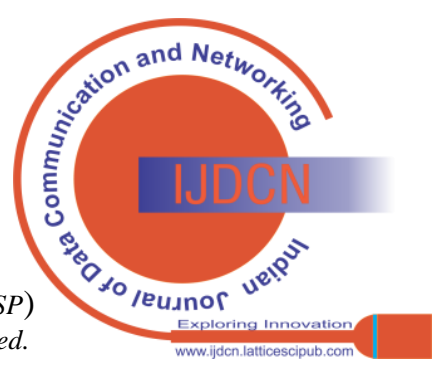




\section{4 .ICT goods exports}

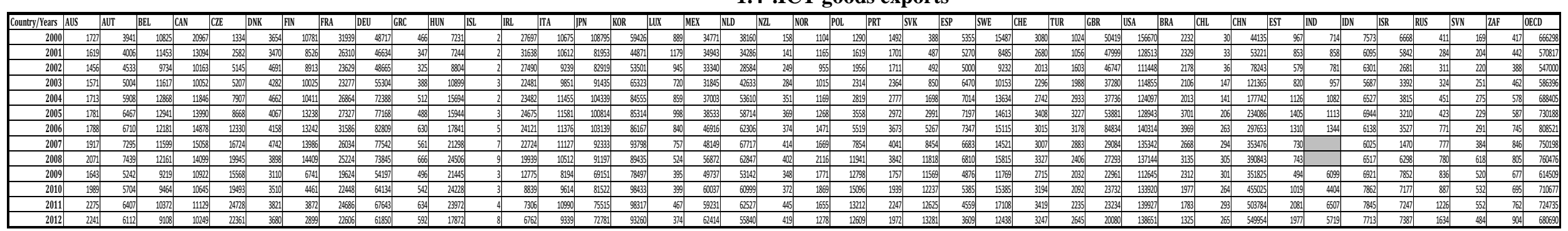

\section{Source: OECD}

\subsection{Access to computers from home}

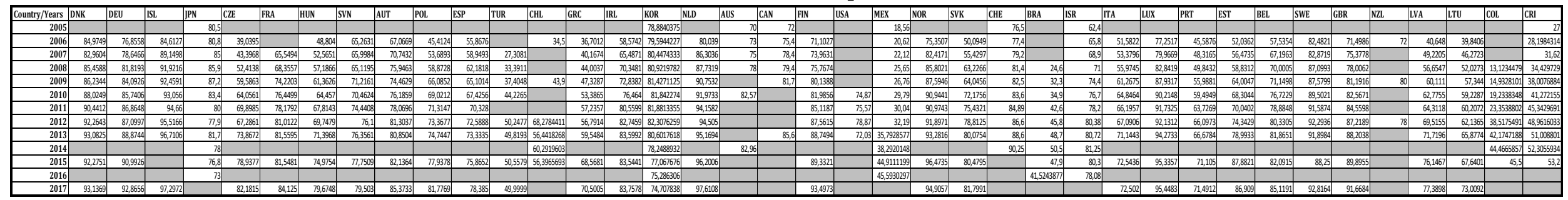

\section{Source: OECD}

\section{6 .Internet access}

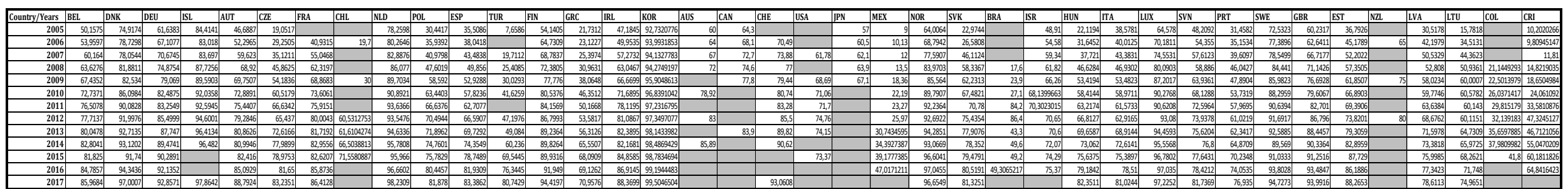

Source: OECD

Retrieval Number:100.1/ijdcn.B5003021221

\section{Published By:}

Lattice Science Publication (LSP)

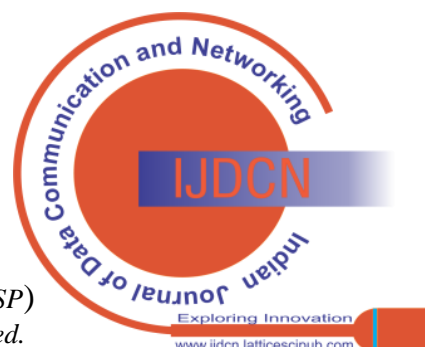


Tables.2. Broadband Access

2.1. Wireless mobile Broadband suscriptions

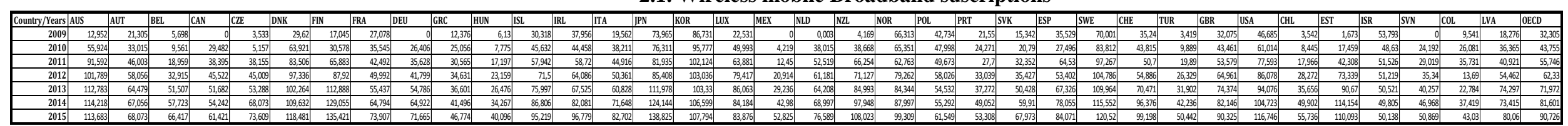

Source: OECD

2.2. Fixed broadband subscriptions

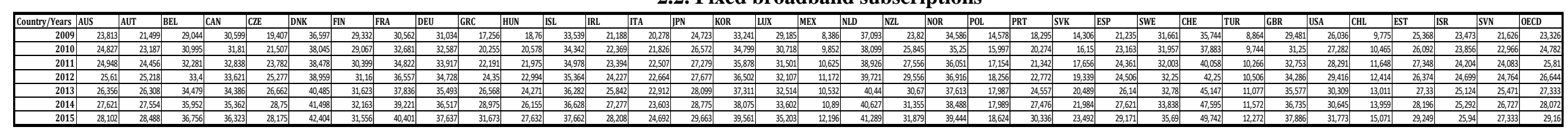

Source: OECD

2.3. Business use of broadband access

\begin{tabular}{|c|c|c|c|c|c|c|c|c|c|c|c|c|c|c|c|c|c|c|c|c|}
\hline Country/Years & ESP & SWE & IRL & NOR & AUT & FRA & LUX & PRT & HUN & CZZE & EST & ISL & DEU & NLD & GBR & POL & SVN & SVK & TUR & ITA \\
\hline 2004 & & & & 58,6585899 & 55,1508496 & & & & & & & & & & & & & 24,448672 & & \\
\hline 2005 & & & & 75,9919493 & 61,4661084 & & & & & & & & 61,2353512 & & & 42,5719628 & 74,4245524 & 46,2328196 & & \\
\hline 2006 & & & & 84,0026766 & 69,8105174 & & & & & 69,4212595 & \begin{tabular}{l|l}
5 & 75,3234609 \\
5
\end{tabular} & & 72,5127296 & & & 46,7174446 & $\begin{array}{l}\text { f. } 75,1428571 \\
5\end{array}$ & 59,8855464 & & \\
\hline 2007 & & & & \begin{tabular}{|l|}
83,87151 \\
\end{tabular} & \begin{tabular}{|l}
73,3592086 \\
\end{tabular} & & & & 66,9761011 & \begin{tabular}{|l}
76,9605522 \\
\end{tabular} & 78,0577116 & & 78,3154268 & & & 53,6240346 & & 74,4928831 & & \\
\hline 2008 & & & & 84,3592252 & 76,93522 & & & & 70,3659132 & \begin{tabular}{|l}
79,3277519 \\
\end{tabular} & \begin{tabular}{|l|l|}
87,5333652 \\
8 & 87365 \\
& 87,53365 \\
\end{tabular} & & 83,4575383 & & & 59,1219091 & & 73,7248603 & & \\
\hline 2009 & 93,0359558 & \begin{tabular}{|l|l|}
88,2989192 \\
\end{tabular} & 76,1060167 & 88,2820558 & \begin{tabular}{|l}
76,0060849 \\
\end{tabular} & 91,6773446 & 0339383 & 7049643 & $3 \quad 74,1931813$ & 77,3099472 & 86,081054 & & 87,8958623 & 86,3837109 & 84,9411572 & 58,4674744 & & 78,3666304 & & 82,9227478 \\
\hline 2010 & \begin{tabular}{|l|}
95,4386716 \\
\end{tabular} & 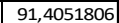 & $\mid$ & 86,9185705 & 82,0584534 & 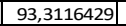 & 87,9118928 & \begin{tabular}{|l|l|l|l}
84,782757 \\
\end{tabular} & 79,608631 & \begin{tabular}{|l|}
86,5242377 \\
\end{tabular} & 88,0794265 & \begin{tabular}{l|l|}
595,43154 \\
\end{tabular} & 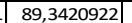 & 90,9315497 & 88,025484 & 69,3426006 & & 78,3204407 & $88,86=$ & 84,1231653 \\
\hline
\end{tabular}

Source: OECD

\subsection{Households with broadband access}

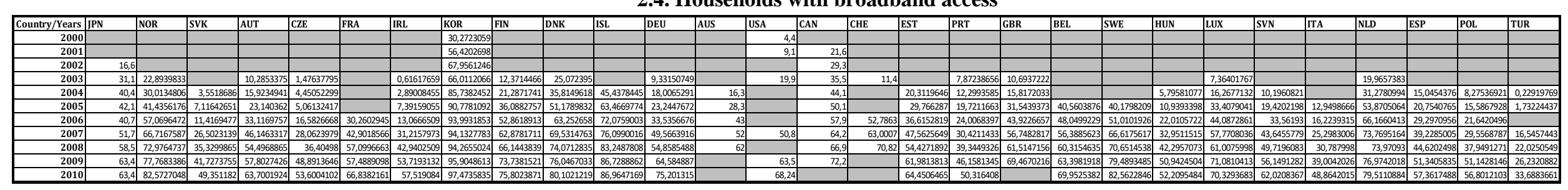

Source: OECD

Retrieval Number:100.1/ijdcn.B5003021221

DOI:10.54105/ijdcn.B5003.061321

Journal Website: www.ijdcn.latticescipub.com
Published By:

Lattice Science Publication (LSP)

(c) Copyright: All rights reserved.

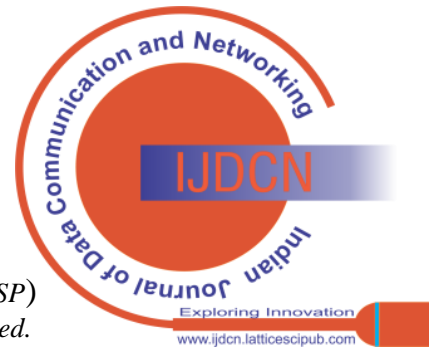

